\title{
My Entrepreneurship Journey: Ireland to the Middle East and America
}

\author{
Kieran Folliard \\ Eapen Chacko (Queblo, Inc. )
}

KEYWORDS: Accommodation \& Food Services, Entrepreneurship, Innovation, Management, Marketing, Product Development, Startups.

I grew up in Ireland, and my family hails from Ballyhaunis in County Mayo. Dad was a small business owner, who used his trusty cab to provide service to our neighbors. Dad provided my first exposure to business issues of competition, pricing and customer service. Mom felt strongly that when I left school I should seek a steady, dependable income working for the civil service. I felt more attracted to business, but wasn't drawn to the idea of working for an old-line, established company.

At that time, university entrepreneurship programs were unknown, and, as luck would have it, an entrepreneurial opportunity came my way. A successful farming family in County Antrim, Northern Ireland wanted to hire workers to join their company, called Masstock, which had more than a half-century's experience in large scale dairy farming. However, their jobs were in Saudi Arabia, where the kingdom's rulers wanted Masstock to help them establish vertically integrated, state-of-the-art dairy farms in the desert! The project's products were planned for export throughout the Persian Gulf states.

This seemed like a bold, audacious or even preposterous project, but everyone knew of the entrepreneurial skills and success of the brothers Alastair and Paddy McGuckin. I badly wanted to join their team, deciding that it might be exciting to get my business experience in a startup, living in a new country and culture, and working for and learning from experienced businessmen. After making a pest of myself during the application process, they invited me to join their team in 1977, and I stayed until 1979.

I received the best business and entrepreneurial education I could have gained by working for this largescale, complex industrial agriculture venture. Because of my passion and work ethic, I was given responsibilities to help implement marketing and

product development strategies for branded dairy products on an international scale. Masstock partnered with HH Sultan bin Mohammed bin Saud Al Kabeer to establish the dairy products brand Almarai in 1977. Today, Almarai is a leading food and beverage brand in the Middle East and North Africa, and it operates the largest vertically integrated dairy company in the world.

Working for entrepreneurs at Masstock was a great choice for me, providing both professional growth and financial rewards, but after three years in the Persian Gulf, I needed a break. A small company in Minneapolis, the Andcor Companies, recruited me to help build their corporate advisory practice, focusing on growth companies being organizationally challenged by their rapid growth. I soon realized, however, that the corporate world wasn't for me.

\section{Beyond Guinness and Irish Stew}

Now, I had to make my entrepreneurial journey my own. This phase is like a love story: full of joy, passion, breakups, restarts and lots of mistakes. Growing up in Ireland, the local pub was a community magnet for social interaction, family events and for discussing things from football to business. In Minneapolis, Irish pubs were places for commuters to grab a quick drink after work, and the food wasn't good enough for people to think of the pub as a destination for dinner.

I opened Kieran's Irish Pub as my first venture with a fervent desire to bring the experience of a modern Irish pub to Minneapolis. It was well received, and sales were good, but the profits weren't there, and we experienced a lot of turnover. My team and I opened a new pub, The Local, in a better location than Kieran's; I employed craftsmen to custom-build the bar in solid, dark wood, with comfortable tables and seating, to recreate that inviting environment I remembered from back home. 
The menu in Irish pubs around the country often revolved around the same set of predictable, food service products, like Irish stew. None of this reflects the character of younger consumers as "foodies" interested in bold flavors, fresh ingredients and local sourcing. We worked with Chef Steven Brown of Tilia and invested to bring our food up to our new standard for Irish pubs. The Local was a great success.

From my first two pubs, I learned that people are more important than the physical environment of a restaurant if you're trying to build a sustainable business. Some owners don't care about high turnover of staff, treating it as a fact of the restaurant world. I don't subscribe to this view.

No matter how good the physical environment -customers take it for granted -- it will have to be refreshed after a few years anyway. However, without staff who don't enjoy coming to work and feel rewarded supported by the management, the customer won't feel like our establishments are top of mind places they can reliably come back to for any occasion. Turnover and burnout hurts sales and profits, as I learned at Kieran's, and it's a lesson for any food service business. Your team, from dishwashers to chefs and management, are critical to success in a difficult business.

Whereas people often come in for a Guinness in an American pub, a good Irish whiskey can be the staple for an Irish pub. Eventually, our environment, food and bar service led to The Local becoming the largest, single establishment purveyor of Jameson Irish Whiskey in the world!

Buoyed by this success, we expanded the pub portfolio to include The Liffey, and Cooper, in a brand new, suburban dining and entertainment complex.

Along the way, I had some significant failures, which are all part of an entrepreneurial journey. If you're striving and growing, some failures are inevitable, as long as they don't sink the ship. We digressed a bit into two tonier establishments, Merchant's and Brasserie Zinc, aimed at a financial district, expense account crowd, and they didn't work. I had to use a second mortgage to extract myself from Brasserie Zinc, but it's all part of the process. During this time, my team, many of whom had been with me for a while, stayed with me. They committed to keep our standards high, to serving our customers well, and looking to the future.

\section{Serving Up a Unique Brand for our Customers}

As a pub owner, thinking about our customers means thinking about the brands we serve. Even though The Local was recognized as the world's largest on-premise establishment for Jameson Irish Whiskey sales, a giant global brand, I felt that our customers were hankering for something else.

We never viewed ourselves as people who just pulled taps for Guinness or poured traditional Irish whiskey. I felt that Irish whiskey had to tweak itself to be enjoyed throughout the year (not just in cold weather), and by women, who preferred cocktails over ice to a neat whiskey. Such a whiskey required a different flavor profile and a smoother style, which traditionalists saw as heresy, but I felt there was a great opportunity for us to create a market for a new style of Irish whiskey, to the benefit of producers, the customers and ourselves.

In order to address a need about which I felt strongly, I had no choice to become an entrepreneur again, this time by creating a new kind of Irish whiskey. I needed to find help developing the whiskey and then to find capacity to distill the product. Capacity in Scotland and Ireland are in short supply, dominated as they are by global beverage companies.

Going back to my roots, I knew that the lone remaining independent distillery in Ireland, Killbeggan Distillery in County Westmeath, was about 70 miles from my family home. I called on them and asked how much of an order I would need to place to get my new whiskey into the distillery's schedule. They told me that I would need a minimum order of 1,400 cases, which was more than the 1,200 cases we were ordering from our vendors! I felt that we would have to stretch, but we could do it. I worked with Noel Sweeney, Killbeggan's master blender, to develop our proprietary blend and flavor profile, which we called "2 Gingers" after my Mother and Aunt, and we were in business as of 2011!

Because I was now a pub owner, or "landlord," and I was also the owner of the major house whiskey brand, the laws said that I had to divest myself of the pubs if we wanted to market 2 Gingers to all fifty states. I really didn't want to do it, but regulation forced me to sell my beloved portfolio of pubs. An entrepreneur can't become too attached to one facet of the business, and a good entrepreneur isn't afraid to share his success with his key employees who were an integral part of it. 
Henry Cousineau, my original investor partner and the key management team led by Peter Killen, who had been one of my key team members for 12 years, bought my ownership in the pubs. The team consists of many members who were also with us, so the sale was within my entrepreneurial family. Don't be afraid of sharing your success with the people who brought your projects success.

\section{Opportunity Is Not Always Unearthed; Sometimes It Knocks}

By 2012, I was working very hard to expand the distribution of 2 GINGERS within Minnesota. Sales had grown impressively to 20,000 cases in Minnesota. However, for an independent brand, nationwide distribution is still hand-to-hand combat with intermediaries and with individual establishments.

Global beverage companies have established powerful nationwide and global distribution networks, supported by large marketing and advertising budgets. Innovating new brands in these large organizations is not their strong suit, and the process is rarely agile and often uneconomic. However, the road for an independent to national distribution of 2 Gingers in a country as large as the United States was going to be too long and too expensive to be a viable business proposition for me.

Nevertheless, an entrepreneur must have passion about the mission and commitment, and it's always a good idea to make friends along the way, like we did with our friends at Killbeggan Distillery. They were great partners in helping us develop our product and giving us a slot in their production schedule. Though our transactions were business, our relationships were as friends too.

So, in 2011, Jim Beam had approached Killbeggan's parent, Cooley, to purchase their two independent distilleries for the Beam portfolio and to handle future acquisitions. In their due diligence process for buying Cooley, Beam execs learned about 2 Gingers and its innovative brand creation from our friends at Killbeggan, who spoke highly about our energy and initiative in creating a new product in the global Irish whiskey category. So, the execs at Beam, who came in looking to buy distilling capacity, also purchased 2 Gingers, a new brand to fold into their portfolio! It couldn't have happened without the friendships that good entrepreneurs develop along their journey. While our acquisition was going on, the Japanese giant Suntory bought Beam, creating a truly global beverage giant, which now also included 2 Gingers, two years after its launch.

\section{Next: Giving Back by Nurturing Entrepreneurs}

As someone who first forayed into the hospitality business through owning pubs, and then ventured into creating a proprietary brand of spirits, it just felt as if expanding into foods would be a good thing. Good food in my pubs had always been a signature for those businesses. Now, several generations are committed to movements like Slow Food, sustainability of agriculture, local sourcing of minimally processed ingredients and humanely raised animals.

I'm not a person who can kick back and relax, so I had a vision to create a food venture in Minneapolis, home to my first ventures and my family's home now. My dream is to support young entrepreneurs pioneering fresh visions for innovative food products. It is a way of giving back to the entrepreneurial community.

In 2014, I purchased a building in Northeast Minneapolis, a rapidly growing and rehabbing neighborhood that was once home to grain millers and brewers. After the purchase and interior tear-down, the charming exterior revealed bones that needed to be removed and replaced at significant expense, but it's all a part of the entrepreneur's journey. Now re-branded as The Food Building, it is the 26,000-square-foot home to several ventures -- and my current challenging and exhilarating project.

I am partnering with some artisan food producers to help them commercialize high-quality, farm-to-table foods that let families and commercial establishments savor the qualities of foods which have become commoditized over time. Red Table Meats uses pork to produce salumi, which are salted and dry-cured meats. The animals are hand-trimmed by co-owner Mike Phillips and his team into artisanal cuts from locally grown, naturally pastured and humanely slaughtered animals; his success at the Craftsman restaurant established Mike as a leader in this traditional method of curing and aging sausage. Mike has sweat equity in the venture of Red Table, and the Food Building organization provides administrative services, finance and marketing support.

Barker's Field Flour and Bread gets locally produced organic grains from around Minnesota and produces 
intensely flavored, full-bodied breads by stone milling the local flours and by using a natural yeasting process. Again, there's no doubt we have a great founder, a good facility, and some good initial response. It remains to be seen if we can create a sustainable business out of it.

I'm very much of a relationship person, and this informs how I build my teams and do my business. I've learned a few things over the years, a lot by observing and more by making mistakes myself. Here are some things I would like to share with you, the current or future entrepreneur.

\section{No Blarney, Just Some Thoughts for Entrepreneurs}

1. There are different financing paths to entering the world of entrepreneurship, e.g. bootstrapping, SBA loans, accelerators and venture capital. Pick the one that resonates with you and your situation, and don't rule out learning by working for an entrepreneur, which will give you first-hand experience. No matter what path you take to learning, your entrepreneurial education is never finished.

2. In the restaurant business, whether it's quick service or white tablecloth, customers' memories of their experience in your establishment are cemented by how they are treated. That's where your whole team comes in. Select wisely, train your managers to build teamwork and camaraderie, and don't be afraid, even as an owner, to show people how you like things to be done.

3. Don't be afraid to share financial rewards from growth or an exit with your loyal team members.

4. As an establishment owner, you can hear from your customers about what they like, don't like, or would like to see on their plates or in their glasses. Maybe there's an entrepreneurial opportunity for you within your existing business.

5. Make friends along the way. Food service is always on a high wire, so don't be afraid to be a friend as well as a customer.

6. Mentor other entrepreneurs. You know what success looks like -- help others leverage what you know so they can find it too.

Additional Search Terms: success stories, entrepreneurs success stories, inspiration, liquor industry, customer service 